\title{
13. PETROCHEMICAL STUDY OF THE BASALTIC BASEMENT OF THE MID-INDIAN RIDGE: LEG 24, DJIBOUTI TO MAURITIUS
}

\author{
Leonid V. Dmitriev, Vernadsky Institute of Geochemistry, Academy of Sciences of the USSR, Moscow
}

Four of eight holes drilled on Leg 24 encountered basaltic basement, and one other (233A) penetrated through a diabasic sill. The position of these holes is shown on an index map of the northwest Indian Ocean (Figure 1).

To date there are 32 chemical analyses (Table 1) for the five holes studied petrographically. These data are sufficient for preliminary petrochemical speculations and for comparison with the chemistry of crestal (oceanic ridge) and continental basalts.

At the outset, Table 1 indicates that the basalts contain various amounts of water: from 1.6 to 8.6 weight percent, the latter for a palagonitized breccia, Sample 235-19-2(4). Water content increases during metamorphism and seawater alteration of basalts, and these processes are accompanied by changes in the concentrations of some elements. Hart (1969), for example, noted that potassium concentration increases with alteration of oceanic basalts. Therefore, it is necessary to examine how water content influences other petrochemical elements in our basalts.

Figure 2 shows the relationship between water content and potassium concentration (atomic percent) in Leg 24 specimens. Here there is a clear positive correlation between $\mathrm{K}$ and $\mathrm{H}_{2} \mathrm{O}$ beginning with a water content of about $3.0 \%$, where the increase in potassium becomes marked. For the most part, in the least-altered samples, potassium content changes relatively little (from 0.1 to 0.3 atomic percent) independent of the water content in the rock; one can assume that such concentrations of potassium are typical of fresh rocks.

A very similar relationship appears for water content and the $\mathrm{Fe}^{3+} / \mathrm{Fe}^{2+}$ (Figure 3).

Except for the higher concentration of potassium, there is no significant correlation between increasing water content and the concentration of major petrochenical components of the Leg 24 rocks. Hence, we can use these analyses for preliminary petrochemical speculations.

Earlier, the author and colleagues (Dmitriev, 1969; 1972; Dmitriev et al., 1972a, 1972b) speculated that the general variations of petrochemical compositions of all the oceanic basalts exposed in the crestal parts of mid-ocean ridges are controlled by the primary composition of oceanic mantle, the physicochemical conditions of its partial melting, and the degree of such melting. This conclusion was based on all the petrochemical data for mid-ocean ridge basalts (about 300 published, plus my analyses) and ultramafic rocks (about 100 analyses) and by evidence from experimental petrology:

The process apparently takes place by the rise of hot mantle material beneath the axial part of the mid-ocean ridges, accompanied by partial melting and the separation of a liquid basaltic phase under the proper tectonic conditions.
The primary (primitive?) mantle has a chemical composition very similar to oceanic lherzolite, to the "pyrolite" of Green and Ringwood (Green and Ringwood, 1963), and to the mantle as calculated by Kuno and Aoki (1970). The melted or removed portion is represented by undifferentiated tholeiitic basalt, and the residual high-temperature material is harzburgite.

A similar scheme was outlined for continental tholeiites and alpine-type ultramafic rocks with associated tholeiites. The main differences in the scheme are that continental tholeiites have a more acid composition, and alpine-type ultramafics have a more basic composition than their counterparts in regions such as mid-ocean ridges (Dmitriev et al., 1972b). These differences could be the results of a different composition for the primary mantle beneath old and more recent oceans, or higher concentrations of water in ancient mantle (yielding melts of more acid composition, up to andesite or dacite [Kushiro, 1972; Allen et al., 1972]), or by a high degree of metamorphism of the ophiolite complexes under crustal conditions.

The petrochemicai relations between mafic and ultramafic rocks for both oceanic and continental regions is illustrated in Figure 4. Here the horizontal axis corresponds to the basicity of rocks and includes the olivine and orthopyroxene components: $\mathrm{S}=\mathrm{Si}-\left(\mathrm{Mg}+\mathrm{Fe}^{\prime}\right), \mathrm{Fe}^{\prime}=$

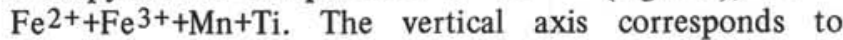
diopside or feldspar components: $\mathrm{A}=\mathrm{A} 1+\mathrm{Ca}+\mathrm{Na}+\mathrm{K}$. In all cases, the quantity being plotted is atomic percent.

In Figure 4 two straight lines connect corresponding fields of basalt and ultramafic rocks. The first (solid) line and the two elongated fields represent the oceanic ridge complexes, overall; the second (dashed) line and two other fields represent all the continental mafic-ultramafic complexes, overall. Points corresponding to average mafic and ultramafic rocks (Table 2) lie along the two straight lines. Here too are shown some average basalt compositions (see Table 2).

Compositions lying on the same straight line have the property of being "complementary," formed within a closed system: the composition at any point on a line can be obtained by combination of proportionate quantities of any two compositions that correspond to points on the same line lying to either side of the point selected.

This complementary characteristic in petrochemical composition of oceanic 1herzolite, harzburgite, and basalt was used as evidence of the kinship of these rocks and as confirmation of the principal idea that lherzolite represents initial mantle, basalt the partial melt, and harzburgite the residual matter. This complementary characteristic was confirmed by correlations between the "S" parameter and all the other petrochemical components (see following Figure 5). 


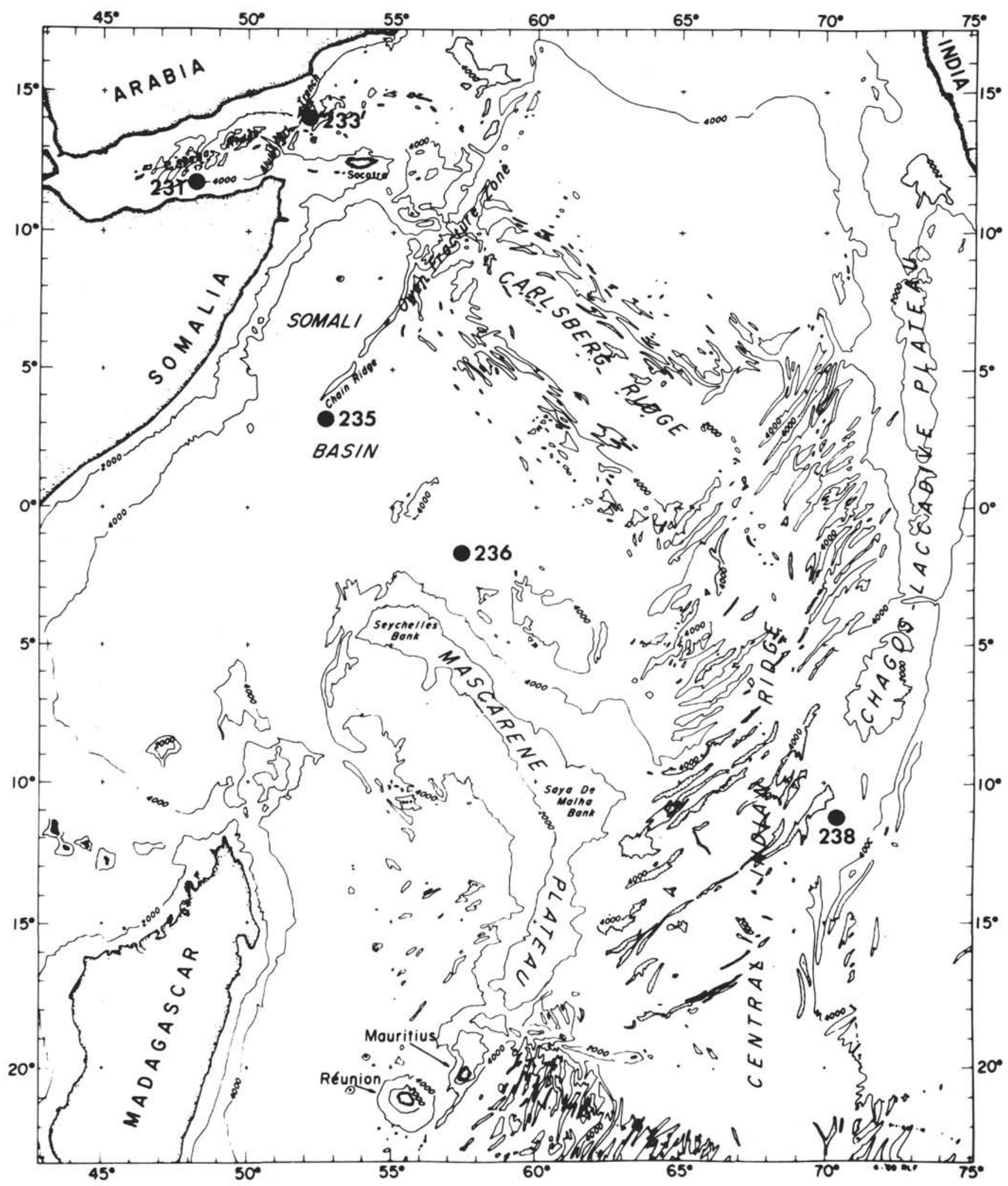

Figure 1. Index map, Leg 24 sites at which igneous rocks were recovered. 
TABLE 1

Major Element Analyses of 32 Mafic Igneous Rocks Recovered from Five Holes on Leg 24

\begin{tabular}{|c|c|c|c|c|c|c|c|c|c|c|c|c|c|c|c|c|}
\hline & \multicolumn{4}{|c|}{ Site 231} & \multicolumn{3}{|c|}{ Hole 233A } & \multicolumn{7}{|c|}{ Site 235} & \multicolumn{2}{|c|}{ Site 236} \\
\hline & $63-2(2)$ & $64-1(2)$ & $64-2(2)$ & 64-3(3) & 9-(1) & $13, \mathrm{CC}(1)$ & $13, \mathrm{CC}(2)$ & $18-1(7)$ & $19-1(10)$ & $19-2(4)$ & $19-3(2)$ & $20-2(21)$ & $20-4(21)$ & $20-5(8)$ & $33-32(4)$ & $34-2(11)$ \\
\hline $\begin{array}{l}\text { Weight Percent } \\
\mathrm{SiO}_{2}\end{array}$ & 48.20 & 48.20 & 48.30 & 48.55 & 48.24 & 45.20 & 45.80 & 46,40 & 46.80 & 44.20 & 44.60 & 48.38 & 47.32 & 47.48 & 5086 & 50.00 \\
\hline $\mathrm{TiO}_{2}$ & 1.40 & 1.35 & 1.50 & 1.35 & 2.10 & 1.60 & 1.80 & 1.30 & 1.10 & 1.10 & 1.00 & 0.90 & 0.90 & 0.90 & 0.80 & 0.80 \\
\hline $\mathrm{Al}_{2} \mathrm{O}_{3}$ & 14.31 & 14.30 & 13.70 & 14.37 & 12.65 & 12.42 & 12.50 & 16.80 & 16.60 & 14.90 & 16.32 & 16.96 & 16.43 & 17.20 & 16.79 & 14.20 \\
\hline $\mathrm{Fe}_{2} \mathrm{O}_{3}$ & 4.97 & 5.59 & 5.48 & 4.74 & 4.71 & 6.08 & 5.59 & 5.73 & 5.48 & 7.02 & 3.92 & 3.93 & 3.66 & 4.05 & 2.83 & 3.34 \\
\hline $\mathrm{FeO}$ & 6.01 & 6.01 & 6.10 & 6.70 & 7.90 & 6.20 & 6.90 & 3.00 & 3.14 & 1.80 & 4.50 & 4.49 & 4.50 & 4.36 & 4.94 & 6.30 \\
\hline $\mathrm{MnO}$ & 0.23 & 0.23 & 0.24 & 0.21 & 0.17 & 0.29 & 0.28 & 0.13 & 0.16 & 0.13 & 0.18 & 0.16 & 0.16 & 0.18 & 0.13 & 0.15 \\
\hline $\mathrm{MgO}$ & 7.14 & 6.70 & 7.53 & 6.90 & 7.31 & 6.52 & 6.25 & 7.74 & 7.80 & 7.87 & 8.45 & 7.40 & 8.00 & 7.50 & 6.80 & 8.27 \\
\hline $\mathrm{CaO}$ & 11.23 & 11.55 & 11.19 & 11.40 & 9.33 & 12.04 & 12.22 & 9.04 & 9.20 & 7.16 & 10.92 & 10.97 & 11.22 & 11.30 & 11.62 & 10.92 \\
\hline $\mathrm{Na}_{2} \mathrm{O}$ & 2.46 & 2.35 & 2.43 & 2.10 & 3.25 & 3.00 & 2.66 & 2.56 & 2.12 & 2.36 & 2.48 & 2.40 & 2.17 & 2.40 & 2.16 & 2.17 \\
\hline $\mathrm{K}_{2} \mathrm{O}$ & 0.23 & 0.23 & 0.10 & 0.07 & 0.10 & 0.09 & 0.07 & 1.00 & 1.24 & 3.18 & 0.32 & 0.56 & 0.26 & 0.28 & 0.29 & 0.16 \\
\hline$\Sigma \mathrm{H}_{2} \mathrm{O}$ & 3.00 & 2.83 & 3.20 & 2.80 & 3.40 & 3.00 & 2.80 & 5.72 & 5.00 & 8.60 & 5.45 & 3.42 & 4.10 & 3.62 & 2.20 & 3.00 \\
\hline Loss on Ignition & & & & & & 2.74 & 1.86 & & 0.8 & 1.6 & 1.2 & & 1.0 & & & \\
\hline Total & 98.18 & 99.34 & 99.77 & 99.19 & 99.16 & 99.18 & 98.73 & 99.42 & 99.44 & 99.92 & 99.34 & 99.56 & 99.72 & 99.27 & 99.42 & 99.31 \\
\hline Atomic Percent & & & & & & & & & & & & & & & & \\
\hline $\mathrm{Si}$ & 47.0 & 47.0 & 46.8 & 47.4 & 47.2 & 45.6 & 45.9 & 45.8 & 46.3 & 45.0 & 44.2 & 46.7 & 46.2 & 45.9 & 48.6 & 48.3 \\
\hline $\mathrm{Ti}$ & 1.0 & 1.0 & 1.1 & 1.0 & 1.5 & 1.2 & 1.4 & 0.9 & 0.8 & 0.9 & 0.8 & 0.6 & 0.7 & 0.6 & 0.6 & 0.6 \\
\hline Al & 16.4 & 16.4 & 15.6 & 16.5 & 14.6 & 14.8 & 14.8 & 19.6 & 19.4 & 17.9 & 19.1 & 19.2 & 18.9 & 19.7 & 18.9 & 16.1 \\
\hline $\mathrm{Fe}^{+3}$ & 3.6 & 4.1 & 4.0 & 3.5 & 3.4 & 4.6 & 4.2 & 4.3 & 4.0 & 5.4 & 2.9 & 2.8 & 2.7 & 2.9 & 2.0 & 2.4 \\
\hline $\mathrm{Fe}^{+2}$ & 4.9 & 4.8 & 5.0 & 5.5 & 6.4 & 5.2 & 5.8 & 2.5 & 2.5 & 1.5 & 3.8 & 3.6 & 3.7 & 3.5 & 4.0 & 5.1 \\
\hline Mn & 0.2 & 0.2 & 0.2 & 0.1 & 0.2 & 0.2 & 0.2 & 0.1 & 0.1 & 0.2 & 0.2 & 0.1 & 0.1 & 0.2 & 0.1 & 0.1 \\
\hline $\mathrm{Mg}$ & 10.3 & 9.7 & 10.9 & 10.0 & 10.6 & 9.4 & 9.3 & 11.3 & 11.5 & 12.0 & 12.5 & 10.6 & 11.6 & 10.8 & 9.6 & 11.9 \\
\hline $\mathrm{Ca}$ & 11.7 & 12.1 & 11.7 & 11.9 & 9.8 & 13.0 & 13.1 & 9.5 & 9.7 & 7.9 & 11.6 & 11.3 & 11.7 & 11.6 & 11.9 & 11.3 \\
\hline $\mathrm{Na}$ & 4.6 & 4.4 & 4.6 & 4.0 & 6.2 & 5.8 & 5.2 & 4.8 & 4.0 & 4.7 & 4.8 & 4.5 & 4.1 & 4.5 & 3.9 & 4.0 \\
\hline K & 0.3 & 0.3 & 0.1 & 0.1 & 0.1 & 0.1 & 0.1 & 1.3 & 1.5 & 4.2 & 0.4 & 0.6 & 0.3 & 0.3 & 0.4 & 0.2 \\
\hline S & 27.0 & 27.2 & 25.6 & 27.3 & 25.1 & 25.0 & 25.0 & 26.7 & 27.4 & 24.6 & 24.2 & 29.0 & 27.4 & 27.9 & 32.3 & 28.2 \\
\hline A & 33.0 & 33.2 & 32.0 & 32.5 & 30.7 & 33.7 & 33.2 & 35.1 & 34.6 & 34.7 & 35.7 & 35.6 & 35.0 & 36.1 & 35.1 & 31.6 \\
\hline $\mathrm{Fe}^{\prime}$ & 9.7 & 10.1 & 10.3 & 10.1 & 11.5 & 11.3 & 11.6 & 7.8 & 7.4 & 8.4 & 7.6 & 7.1 & 7.2 & 7.2 & 6.7 & 8.2 \\
\hline
\end{tabular}

Note: Parameters: $\mathrm{S}=\mathrm{Si}-\left(\mathrm{Mg}+\mathrm{Fe}^{\prime}\right) ; \mathrm{A}=\mathrm{Al}+\mathrm{Ca}+\mathrm{Na}+\mathrm{K} ; \mathrm{Fe}^{\prime}=\mathrm{Fe}^{+3}+\mathrm{Fe}^{+2}+\mathrm{Mn}+\mathrm{Ti}$.

Analyst: A. Lebedkova. Numbers in parentheses are the sequence of rock samples in this section. 
TABLE 1 - Continued

\begin{tabular}{|c|c|c|c|c|c|c|c|c|c|c|c|c|c|c|c|c|}
\hline & \multicolumn{5}{|c|}{ Site 236} & \multicolumn{11}{|c|}{ Site 238} \\
\hline & $35-1(1)$ & $35-2(8)$ & $36-1(2)$ & $36-2(7)$ & $37-1(15)$ & $55-2(3)$ & $57-2(1)$ & $57-3(7)$ & $58-3(2)$ & $59-1(3)$ & $59-2(4)$ & $60-2(1)$ & $61-2(15)$ & $61-4(13)$ & $64-1(10)$ & $64-2(9)$ \\
\hline \multicolumn{17}{|c|}{ Weight Percent } \\
\hline $\mathrm{SiO}_{2}$ & 49.98 & 48.86 & 49.43 & 49.65 & 50.00 & 48.50 & 47.96 & 48.60 & 48.48 & 48.50 & 48.50 & 48.30 & 48.82 & 48.60 & 48.56 & 47.50 \\
\hline $\mathrm{TiO}_{2}$ & 0.90 & 0.70 & 0.80 & 0.70 & 0.70 & 1.10 & 1.30 & 1.30 & 1.20 & 1.30 & 1.40 & 1.30 & 1.30 & 1.50 & 1.40 & 1.30 \\
\hline $\mathrm{Al}_{2} \mathrm{O}_{3}$ & 15.13 & 15.00 & 14.39 & 15.05 & 14.80 & 14.45 & 14.73 & 14.75 & 14.85 & 14.88 & 13.81 & 14.62 & 14.73 & 14.56 & 14.37 & 14.84 \\
\hline $\mathrm{Fe}_{2} \mathrm{O}_{3}$ & 3.65 & 5.32 & 4.16 & 4.60 & 3.20 & 5.31 & 4.71 & 3.45 & 4.74 & 3.75 & 3.69 & 5.29 & 4.80 & 4.09 & 5.82 & 6.76 \\
\hline $\mathrm{FeO}$ & 6.10 & 4.45 & 5.60 & 5.00 & 6.27 & 5.57 & 6.39 & 7.90 & 5.74 & 7.18 & 7.72 & 6.10 & 5.96 & 6.46 & 5.20 & 4.96 \\
\hline $\mathrm{MnO}$ & 0.15 & 0.14 & 0.17 & 0.16 & 0.20 & 0.17 & 0.17 & 0.17 & 0.17 & 0.16 & 0.17 & 0.17 & 0.17 & 0.16 & 0.13 & 0.19 \\
\hline $\mathrm{MgO}$ & 7.94 & 8.29 & 8.65 & 8.23 & 8.00 & 7.70 & 7.20 & 6.94 & 6.64 & 7.32 & 7.72 & 7.52 & 7.03 & 6.72 & 6.37 & 5.87 \\
\hline $\mathrm{CaO}$ & 10.80 & 9.70 & 10.71 & 9.90 & 9.31 & 12.86 & 12.40 & 12.25 & 12.40 & 11.46 & 11.73 & 12.10 & 12.40 & 12.10 & 12.37 & 13.00 \\
\hline $\mathrm{Na}_{2} \mathrm{O}$ & 1.97 & 2.21 & 2.16 & 2.19 & 3.44 & 2.16 & 2.40 & 2.42 & 2.40 & 2.39 & 2.70 & 2.40 & 2.40 & 2.83 & 2.84 & 2.41 \\
\hline $\mathrm{K}_{2} \mathrm{O}$ & 0.17 & 0.50 & 0.32 & 0.46 & 0.40 & 0.22 & 0.15 & 0.06 & 0.17 & 0.06 & 0.08 & 0.15 & 0.09 & 0.12 & 0.28 & 0.39 \\
\hline $\mathrm{\Sigma H}_{2} \mathrm{O}$ & 2.55 & 4.76 & 3.26 & 3.25 & 3.40 & 1.61 & 2.25 & 1.70 & 2.38 & 2.30 & 2.24 & 2.15 & 2.23 & 2.30 & 2.30 & 2.50 \\
\hline Total & $\overline{99.34}$ & $\overline{99.93}$ & $\overline{99.65}$ & $\overline{99.19}$ & 99.72 & $\overline{99.65}$ & $\overline{99.66}$ & $\overline{99.54}$ & $\overline{99.17}$ & $\overline{99.30}$ & $\overline{99.76}$ & $\overline{100.10}$ & $\overline{99.93}$ & $\overline{99.44}$ & $\overline{99.64}$ & $\overline{99.72}$ \\
\hline \multicolumn{17}{|c|}{ Atomic Percent } \\
\hline $\mathrm{Si}$ & 48.2 & 47.8 & 47.7 & 48.1 & 47.7 & 46.4 & 46.1 & 46.4 & 46.9 & 46.7 & 46.5 & 46.2 & 46.6 & 46.8 & 46.8 & 46.0 \\
\hline $\mathrm{Ti}$ & 0.6 & 0.5 & 0.6 & 0.5 & 0.5 & 0.8 & 0.9 & 0.9 & 0.9 & 0.9 & 1.0 & 0.9 & 0.9 & 1.1 & 1.0 & 0.9 \\
\hline $\mathrm{Al}$ & 17.2 & 17.2 & 16.3 & 17.1 & 16.6 & 16.2 & 16.6 & 16.6 & 16.9 & 16.9 & 15.5 & 16.4 & 16.6 & 16.4 & 16.3 & 16.9 \\
\hline $\mathrm{Fe}^{+3}$ & 2.6 & 3.9 & 3.0 & 3.4 & 2.3 & 3.8 & 3.3 & 2.5 & 3.4 & 2.7 & 2.6 & 3.8 & 3.5 & 3.0 & 4.2 & 4.9 \\
\hline $\mathrm{Fe}^{+2}$ & 4.9 & 3.6 & 4.5 & 4.1 & 5.0 & 4.5 & 5.1 & 6.3 & 4.6 & 5.8 & 6.1 & 4.9 & 4.8 & 5.2 & 4.2 & 4.0 \\
\hline Mn & 0.1 & 0.1 & 0.2 & 0.1 & 0.2 & 0.2 & 0.2 & 0.2 & 0.2 & 0.1 & 0.2 & 0.2 & 0.2 & 0.1 & 0.1 & 0.2 \\
\hline $\mathrm{Mg}$ & 11.4 & 12.1 & 12.4 & 11.8 & 11.3 & 10.9 & 10.3 & 9.9 & 9.6 & 10.5 & 11.0 & 10.7 & 10.1 & 9.6 & 9.1 & 8.4 \\
\hline $\mathrm{Ca}$ & 11.2 & 10.1 & 11.0 & 10.3 & 9.5 & 13.1 & 12.7 & 12.6 & 12.8 & 11.8 & 12.0 & 12.4 & 12.7 & 12.5 & 12.7 & 13.5 \\
\hline $\mathrm{Na}$ & 3.6 & 4.1 & 4.0 & 4.1 & 6.4 & 3.9 & 4.5 & 4.5 & 4.5 & 4.5 & 5.0 & 4.5 & 4.5 & 5.2 & 5.3 & 4.5 \\
\hline $\mathrm{K}$ & 0.2 & 0.6 & 0.3 & 0.5 & 0.5 & 0.2 & 0.2 & 0.1 & 0.2 & 0.1 & 0.1 & 0.2 & 0.1 & 0.1 & 0.3 & 0.5 \\
\hline $\mathrm{S}$ & 28.6 & 27.6 & 27.0 & 28.2 & 28.4 & 26.6 & 26.3 & 26.6 & 28.2 & 26.7 & 25.6 & 25.7 & 27.1 & 27.8 & 28.2 & 27.8 \\
\hline A & 32.2 & 32.0 & 31.6 & 32.0 & 33.0 & 33.4 & 34.0 & 33.8 & 34.4 & 33.3 & 32.6 & 33.5 & 33.9 & 34.2 & 34.6 & 35.4 \\
\hline $\mathrm{Fe}^{\prime}$ & 8.2 & 8.1 & 8.3 & 8.1 & 8.0 & 9.3 & 9.5 & 9.9 & 9.1 & 9.5 & 9.9 & 9.8 & 9.4 & 9.4 & 9.5 & 10.0 \\
\hline
\end{tabular}

Note: Parameters: $\mathrm{S}=\mathrm{Si}-\left(\mathrm{Mg}+\mathrm{Fe}^{\prime}\right) ; \mathrm{A}=\mathrm{Al}+\mathrm{Ca}+\mathrm{Na}+\mathrm{K} ; \mathrm{Fe}^{\prime}=\mathrm{Fe}^{+3}+\mathrm{Fe}^{+2}+\mathrm{Mn}+\mathrm{Ti}$.

Analyst: A. Lebedkova. Numbers in parentheses are the sequence of rock samples in this section. 
TABLE 2

Major Element Composition, Calculated Water Free, of Various Mafic and Ultramafic Igneous Rocks and Their Postulated Species

\begin{tabular}{|c|c|c|c|c|c|c|c|c|c|c|c|c|c|c|c|c|c|c|}
\hline \multicolumn{19}{|c|}{ Column } \\
\hline & 1 & 2 & 3 & 4 & 5 & 6 & 7 & 8 & 9 & 10 & 11 & 12 & 13 & 14 & 15 & 16 & 17 & 18 \\
\hline \multicolumn{19}{|l|}{$\begin{array}{l}\text { Weight } \\
\text { Percent }\end{array}$} \\
\hline $\mathrm{SiO}_{2}$ & 45.4 & 45.8 & 40.49 & 40.65 & 43.92 & 45.20 & 45.0 & 49.31 & 49.34 & 50.83 & 50.19 & 50.86 & 47.78 & 48.22 & 52.1 & 50.48 & 48.24 & 49.6 \\
\hline $\mathrm{TiO}_{2}$ & 0.10 & 0.2 & 0.02 & 0.11 & 0.10 & 0.71 & 0.36 & 1.39 & 1.49 & 2.03 & 0.75 & 1.04 & 2.22 & 1.48 & 1.7 & 1.45 & 0.97 & 1.4 \\
\hline $\mathrm{Al}_{2} \mathrm{O}_{3}$ & 1.7 & 3.7 & 0.86 & 1.25 & 4.82 & 3.54 & 4.1 & 16.15 & 17.04 & 14.07 & 17.58 & 17.73 & 15.33 & 15.18 & 16.1 & 15.34 & 17.88 & 16.3 \\
\hline $\mathrm{Fe}_{2}^{2} \mathrm{O}_{3}^{3}$ & & & 2.84 & 2.53 & 2.20 & 0.48 & & 2.41 & 1.99 & 2.88 & 2.84 & 3.92 & 4.09 & 3.18 & 5.2 & 3.84 & 3.16 & 2.5 \\
\hline $\mathrm{FeO}$ & $8.4^{a}$ & $8.3^{a}$ & 5.54 & 6.15 & 6.34 & 8.04 & $11.0^{\mathrm{a}}$ & 6.79 & 6.82 & 9.06 & 7.19 & 6.33 & 7.51 & 9.32 & 7.2 & 7.78 & 5.95 & 7.2 \\
\hline $\mathrm{MnO}$ & 0.1 & 0.1 & 0.16 & 0.18 & 0.19 & 0.14 & 0.16 & 0.16 & 0.17 & 0.18 & 0.25 & 0.17 & 0.15 & 0.20 & 0.2 & 0.20 & 0.13 & 0.2 \\
\hline $\mathrm{MgO}$ & 42.9 & 38.8 & 46.32 & 42.36 & 36.81 & 37.48 & 33.0 & 7.99 & 7.19 & 6.34 & 7.39 & 5.37 & 6.99 & 6.22 & 4.7 & 5.79 & 7.51 & 7.6 \\
\hline $\mathrm{CaO}$ & 0.7 & 2.3 & 0.70 & 1.29 & 3.57 & 3.08 & 4.0 & 11.78 & 11.72 & 10.42 & 10.50 & 9.81 & 9.00 & 10.47 & 8.4 & 8.94 & 10.99 & 11.4 \\
\hline $\mathrm{Na}_{2} \mathrm{O}$ & 0.1 & 0.2 & 0.10 & 0.29 & 0.63 & 0.57 & 0.68 & 2.82 & 2.73 & 2.23 & 2.75 & 2.69 & 2.85 & 2.22 & 3.0 & 3.07 & 2.55 & 2.7 \\
\hline $\mathrm{K}_{2} \mathrm{O}$ & 0.02 & 0.03 & 0.04 & 0.13 & 0.21 & 0.13 & & 0.26 & 0.16 & 0.82 & 0.40 & 1.00 & 1.31 & 0.75 & 1.4 & 0.97 & 0.89 & 0.2 \\
\hline \multicolumn{19}{|l|}{ Atomic } \\
\hline $\mathrm{Si}$ & 37.8 & 38.7 & 34.19 & 35.56 & 37.63 & 38.3 & 39.4 & 46.0 & 46.3 & 48.4 & 46.5 & 48.0 & 45.8 & 47.2 & 49.4 & 48.3 & 45.31 & 46.3 \\
\hline $\mathrm{Ti}$ & 0.10 & 0.2 & 0.02 & 0.05 & 0.05 & 0.4 & 0.3 & 1.0 & 1.1 & 1.4 & 0.5 & 0.7 & 1.6 & 1.1 & 1.2 & 1.0 & 0.67 & 1.0 \\
\hline $\mathrm{Al}$ & 1.7 & 3.6 & 0.86 & 1.31 & 4.82 & 3.5 & 4.2 & 17.7 & 18.9 & 15.7 & 19.3 & 19.9 & 17.3 & 17.2 & 17.9 & 17.2 & 19.88 & 17.9 \\
\hline $\mathrm{Fe}^{+3}$ & & & 1.77 & 1.67 & 1.43 & 0.3 & & 1.7 & 1.3 & 2.1 & 1.9 & 2.7 & 3.0 & 2.3 & 3.7 & 2.8 & 2.19 & 1.8 \\
\hline $\mathrm{Fe}^{+2}$ & $5.8^{\mathrm{a}}$ & $5.8^{\mathrm{a}}$ & 3.90 & 4.51 & 4.51 & 5.7 & $8.0^{\mathrm{a}}$ & 5.3 & 5.3 & 7.2 & 5.6 & 5.0 & 6.0 & 7.4 & 5.7 & 6.2 & 4.62 & 5.6 \\
\hline $\mathrm{Mn}$ & 0.1 & 0.1 & 0.10 & 0.15 & 0.15 & 0.1 & 0.1 & 0.1 & 0.1 & 0.2 & 0.2 & 0.1 & 0.1 & 0.2 & 0.2 & 0.2 & 0.05 & 0.2 \\
\hline $\mathrm{Mg}$ & 53.3 & 48.8 & 58.28 & 55.14 & 49.91 & 47.4 & 43.1 & 11.1 & 10.1 & 9.0 & 10.2 & 7.5 & 10.0 & 8.9 & 6.3 & 8.2 & 10.49 & 10.6 \\
\hline $\mathrm{Ca}$ & 0.6 & 2.1 & 0.65 & 1.20 & 3.23 & 2.8 & 3.7 & 11.7 & 11.8 & 10.6 & 10.4 & 9.9 & 9.3 & 10.7 & 8.5 & 9.2 & 11.05 & 11.4 \\
\hline $\mathrm{Na}$ & 0.2 & 0.4 & 0.20 & 0.31 & 1.01 & 1.0 & 1.2 & 5.1 & 4.9 & 3.0 & 5.0 & 5.0 & 5.3 & 4.1 & 5.4 & 5.7 & 4.62 & 4.9 \\
\hline K & 0.02 & 0.03 & 0.05 & 0.10 & 0.20 & 0.1 & & 0.3 & 0.2 & 1.1 & 0.4 & 1.2 & 1.6 & 0.9 & 1.7 & 1.2 & 1.12 & 0.3 \\
\hline S & -21.9 & -16.5 & -29.9 & -25.9 & -14.4 & -16.0 & -12.1 & 26.8 & 28.4 & 27.5 & 28.1 & 32.0 & 25.1 & 27.3 & 32.3 & 29.9 & 27.3 & 27.1 \\
\hline A & 2.5 & 6.1 & 1.8 & 2.9 & 9.3 & 7.4 & 9.1 & 34.8 & 35.8 & 30.5 & 35.1 & 36.0 & 33.5 & 32.9 & 33.5 & 33.3 & 36.7 & 34.5 \\
\hline $\mathrm{Fe}^{\prime}$ & 6.4 & 6.5 & 5.8 & 6.4 & 6.1 & 6.9 & 8.4 & 8.1 & 7.8 & 10.9 & 8.2 & 8.5 & 10.7 & 11.0 & 10.8 & 10.2 & 7.5 & 8.6 \\
\hline
\end{tabular}

Total iron: $\mathrm{Fe}^{+3}+\mathrm{Fe}^{+2}$. Parameters: $\mathrm{S}=\mathrm{Si}-\left(\mathrm{Mg}+\mathrm{Fe}^{\prime}\right) ; \mathrm{A}=\mathrm{Al}+\mathrm{Ca}+\mathrm{Na}+\mathrm{K} ; \mathrm{Fe}^{\prime}=\mathrm{Fe}^{+3}+\mathrm{Fe}^{+2}+\mathrm{Mn}+\mathrm{Ti}$

Note: Sources are as follows for each column:

(1) Oceanic harzburgite (average of 72 analyses: Dmitriev); (2) Oceanic lherzolite (average of 68 analyses: Dmitriev); (3) Dunite (Daly, 1933, Table 1, p. 20); (4) Harzburgite (Daly, 1933, Table 1, p. 20); (5) Lherzolite (Daly, 1933, Table 1, p. 20); (6) "Pyrolite III"(Ringwood, 1966); (7) "Mantle," as calculated by Kuno and Aoki (1970); (8) Oceanic tholeiite (average of

150 analyses: Dmitriev); (9) Oceanic tholeiite (Engel et al, 1965); (10) Tholeiite (Nockolds, 1954); (11) High alumina basalt (Kuno, 1960); (12) Basalt, andesitic variety (Kutolin, 1972);

(13) Basalt, continental olivine-basalt variety (Kutolin, 1972); (14) Traps, ancient shield areas (Kutolin, 1972); (15) Traps, young shield areas (Kutolin, 1972); (16) Diabase (Daly, 1933,

Table 1, p. 18); (17) Gabbro, all (Daly, 1933, Table 1, p. 17); (18) Tholeiite, Mid-Indian Ocean Ridge system (average of 65 analyses: Dmitriev). 


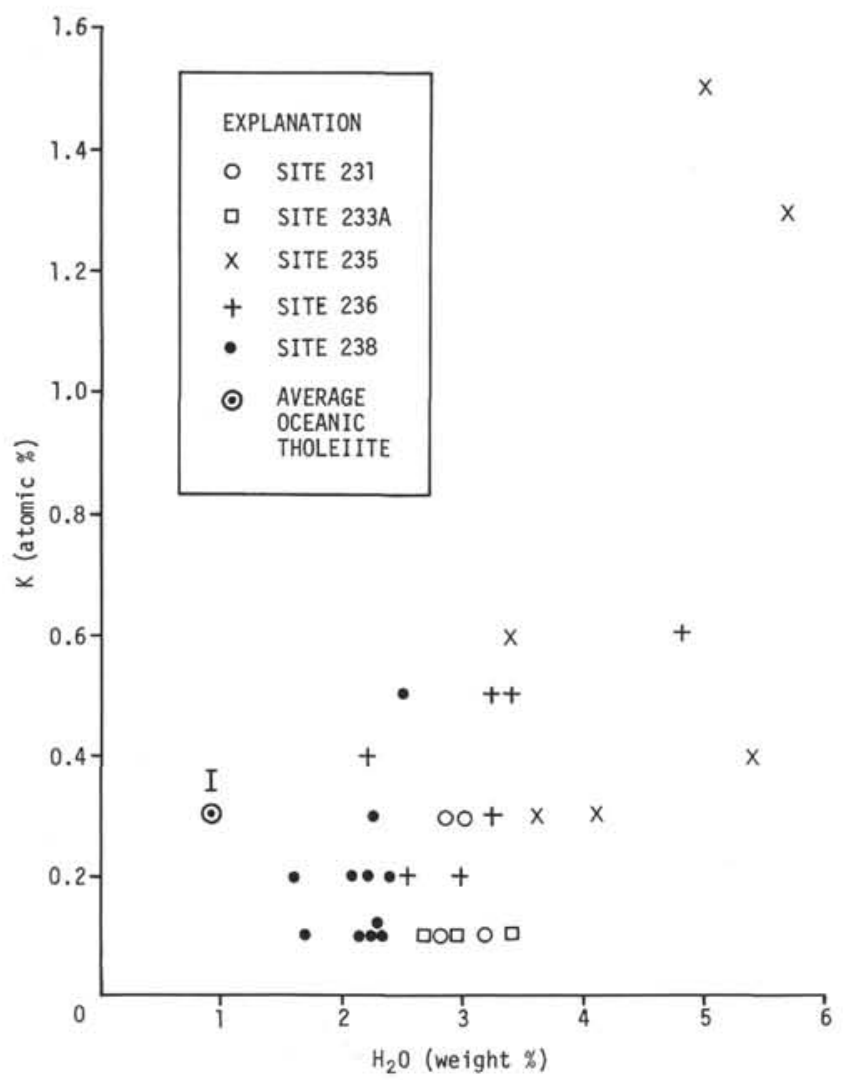

Figure 2. $\mathrm{K}$, in atomic percent, vs. $\mathrm{H}_{2} \mathrm{O}$ content in basalts from Leg 24. I: average oceanic tholeiite.

Figure 4 also shows the direction of change of tholeiitic composition toward picrite, alkali basalt, andesite, and anorthosite, and the general trend of crystallization differentiation. The length of the oceanic basalt field depends mainly on the degree of melting and the separation of the melt from the primary lherzolite. The width of this field depends on the primitive composition of this initial lherzolite and, probably, on crystal differentiation of the basaltic magma.

It is enlightening to plot the data from Glomar Challenger's basalts on this diagram, particularly in that our analyzed specimens have very good positioning on the Indian Ocean sea floor relative to the magnetic anomaly patterns and have supporting paleontologic data as to ages, while the basalt field plotted on Figure 4 reflects only general tendencies for oceanic ridge basalts.

Such plotting of data listed in Tables 1 and 2 was carried out on an expanded scale for mafic rocks only (Figure 5A-I) and, on a smaller scale, for ultramafic and mafic rocks (Figure 6A-H).

These plots show that each hole is characterized by basalt of a specific composition. Analyses for each site form nearly isolated compact fields. This is seen clearly on the diagrams "A-S" (Figure 5A) and "Si-S" (Figure 5B). Other diagrams show that basalts from Site 231 (empty circles) and Site 238 (filled circles) of Miocene(?) age have similar properties and are localized in a common region (see diagrams for "A1-S", Figure 5D; "Fe' $S$ ", Figure 5E; "Mg-S", Figure 5F).

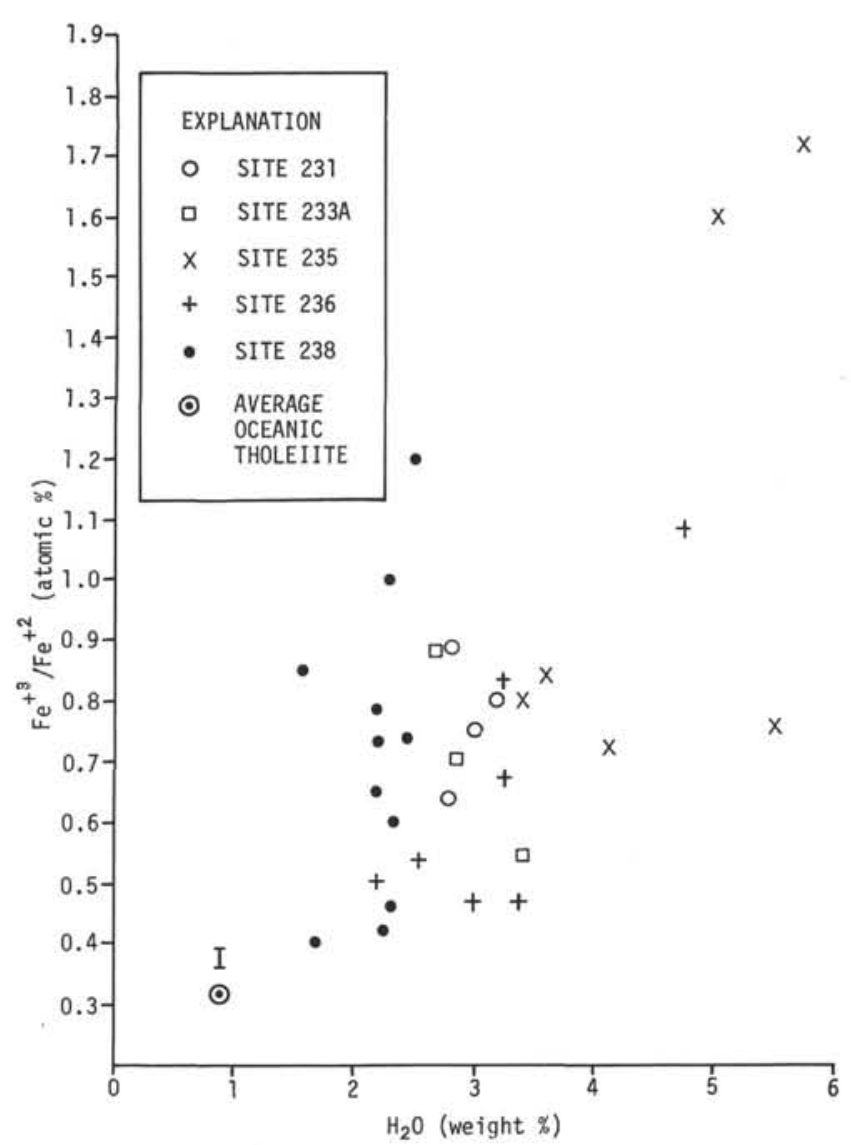

Figure 3. Ferric-ferrous iron ratio, $\mathrm{Fe}^{3+} / \mathrm{Fe}^{2+}$, vs. $\mathrm{H}_{2} \mathrm{O}$ content in basalts from Leg 24. I: average oceanic tholeiite.

Compositions of the basalts from Site 235 (Symbol "X") and Site 236 (Symbol "+") of supposed Upper Cretaceous or Paleocene age form elongated fields in the "A-S" diagram (Figure 5A) that lie to either side of the younger basalts. Other diagrams in this series show that basalts from Sites 235 and 236 are less uniform in composition than are the young basalts.

The positions and the length of all the fields of the Leg 24 basalts on the diagrams, in total, indicate that the components of these basalts could be derived from oceanic or continental lherzolites.

The diabasic (doleritic) sill penetrated at Site 233A ("squares") has a composition unlike that of the flows and pillow basalts from Sites 231, 235, 236, and 238.

Now, what are the differences among each of these basalt groups? Where is their place in the general scheme of mantle evolution? In what does the nature of these differences lie? All of the diagrams portraying a connection between the mafic and ultramafic rocks indicate that all of the Leg 24 basalts, like all of the oceanic or continental tholeiites, can be formed by extraction from an initial lherzolitic mantle.

The orientation of the longer (major) axes of the basaltic fields of each hole (except 233A) and the generalized field of all oceanic basalts are more or less similar. This orientation is especially clear for Sites 231,236 , and 238 . 


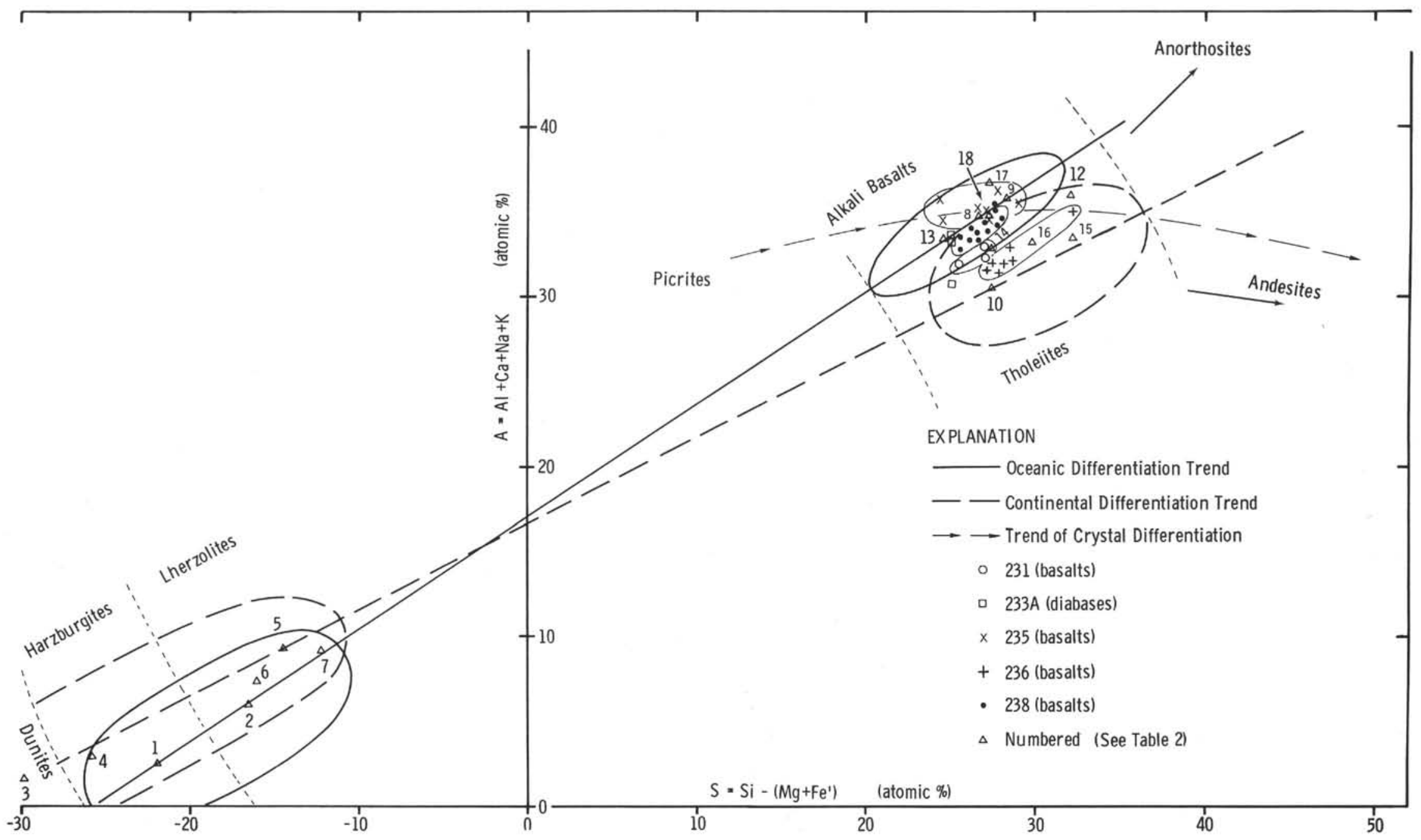

Figure 4. Complementary petrochemical relationships between mafic and ultramafic rocks and the distribution of the basaltic compositions in terms of "A" vs. "S", of "basement" rocks from the Indian Ocean drilled on Leg 24. The points labeled 1 through 18 correspond to average composition of the oceanic and continental mafic and ultramafic species as listed in Table 2. 

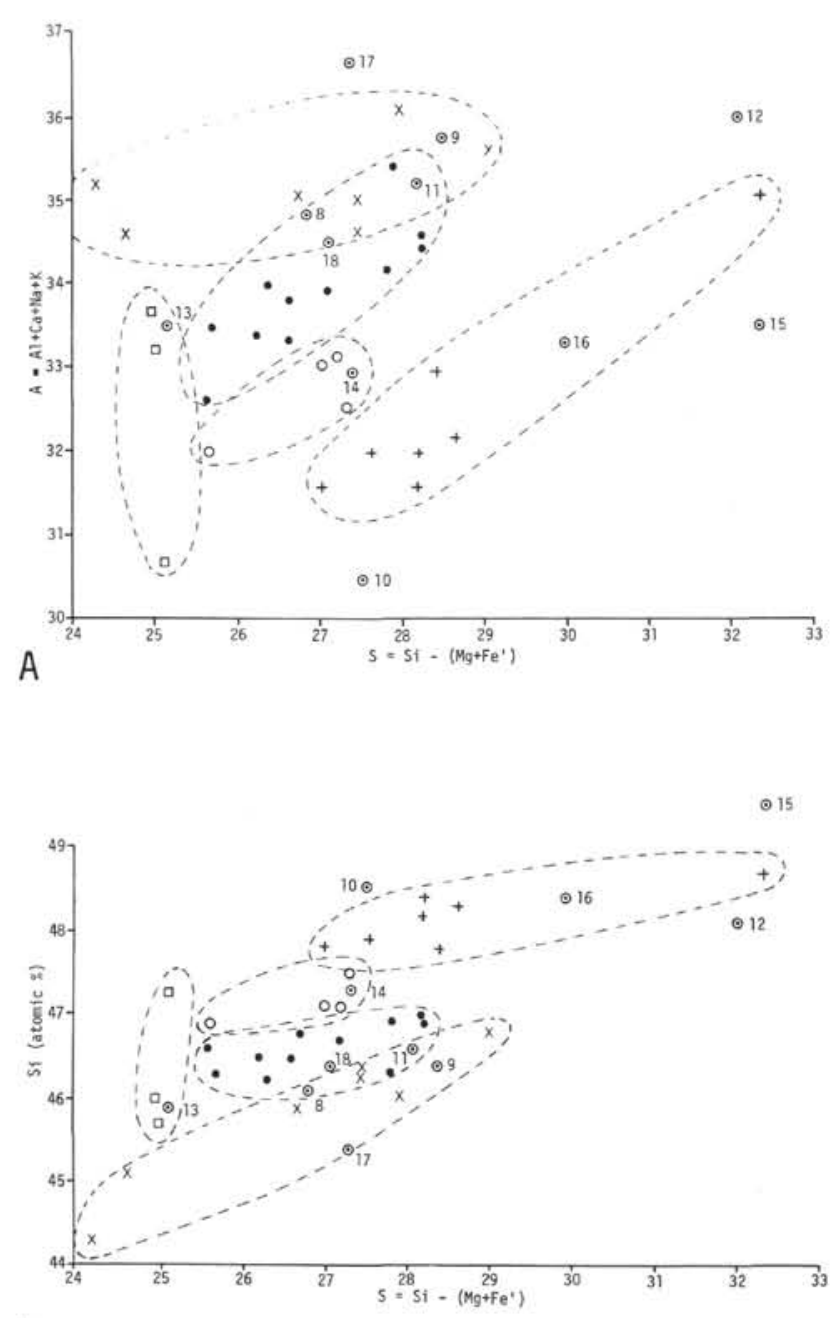

B

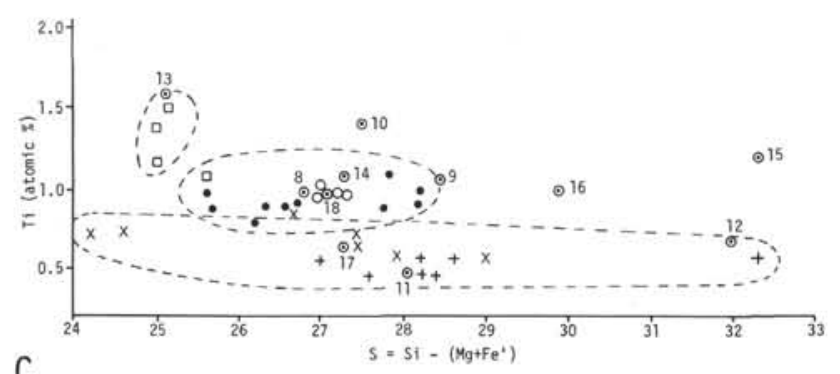

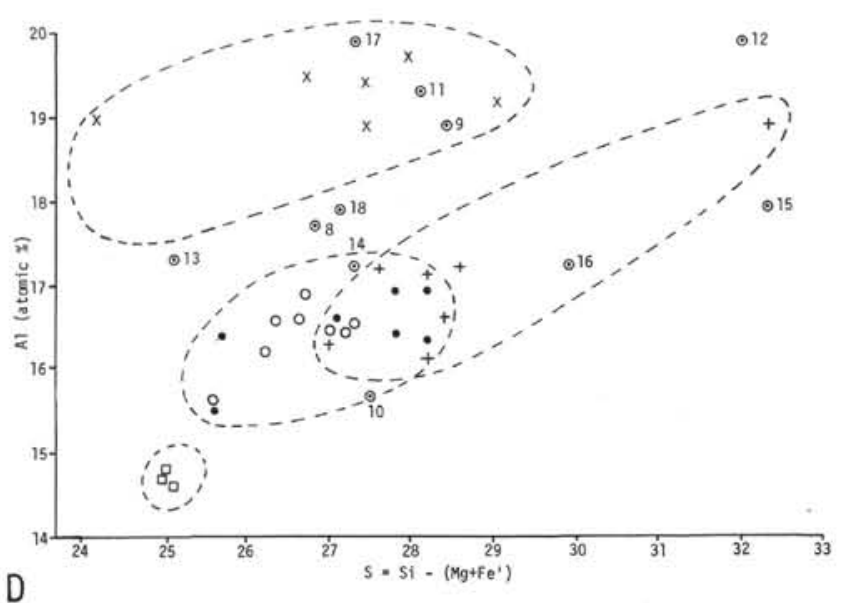

D
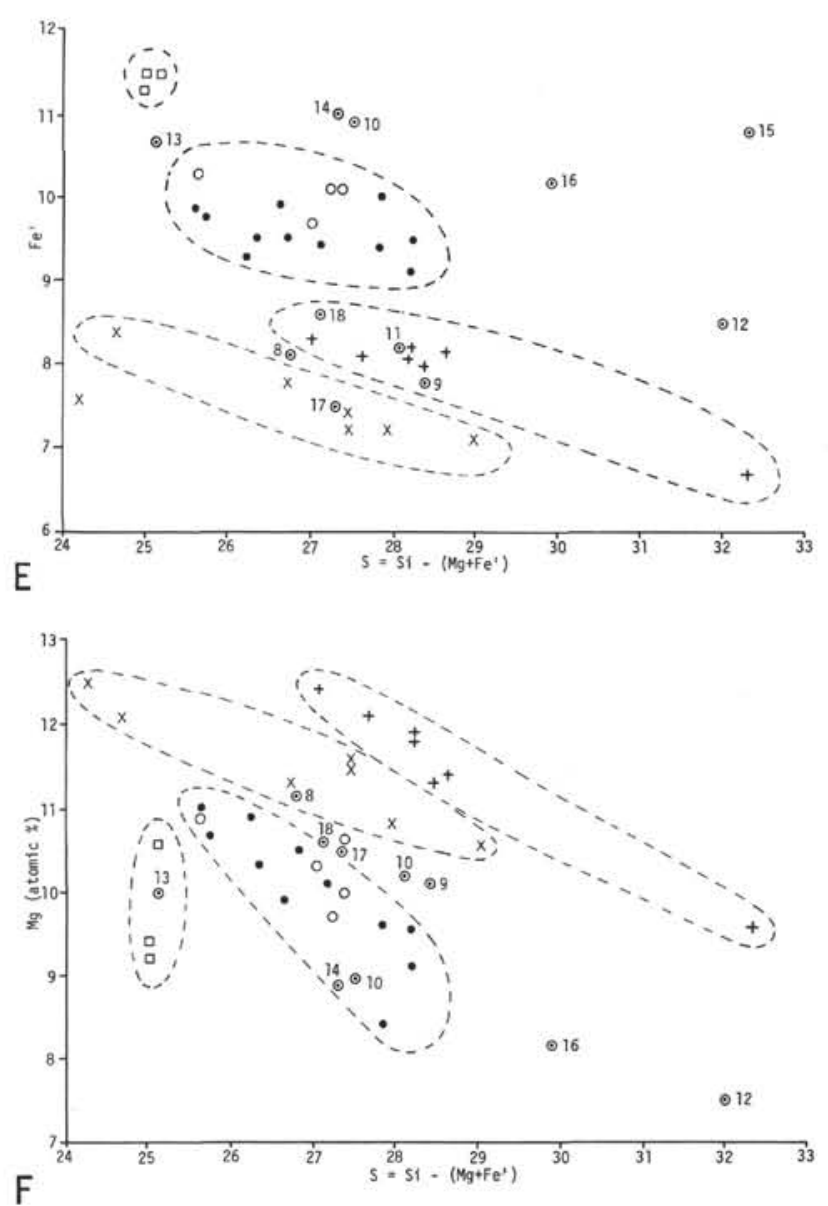

Figure 5. Correlation between parameters " $A$ " and " $S$ " (A), and between parameter " $S$ " and several other petrochemical components (B) Si; (C) Ti; (D) $\mathrm{Al}$; (E) $\mathrm{Fe}^{\prime}$; (F) $\mathrm{Mg}$; (G) Ca; (H) Na; (I) K. Site symbols same as for Figure 2; plotted maficultramafic types $(10,12,16$, etc.) are those from Table 2.

The elongation of the field for Site 235 is almost horizontal and very similar to the main trend in changing petrochemical composition due to crystallization differentiation for picrite to andesite-dacite. A slight influence of this process is reflected in the appearance of basalts depleted in $\mathrm{Si}$ and enriched in $\mathrm{Mg}-235-19-3(21)$ and 235-19-2(4)-and relatively depleted in $\mathrm{Al}$ and $\mathrm{Ca}$, Sample 235-19-2(4). Such basalts could be representatives of cumulates. The primary magma for this basaltic group probably was saturated by $\mathrm{Al}$ and depleted in $\mathrm{Si}$ relative to the usual oceanic tholeiite. Most probably the group of analyses for Site 235 characterizes the slightly differentiated magma which is close to the average gabbro of Daly (1933; Table 2, Column 17).

The fields of the young basalts (Sites 231 and 238) lie within the overall oceanic basalt field but they tend toward the average continental tholeiite of Nockolds (1954; Table 2, Column 10). The field at Site 236 also displays this trend 


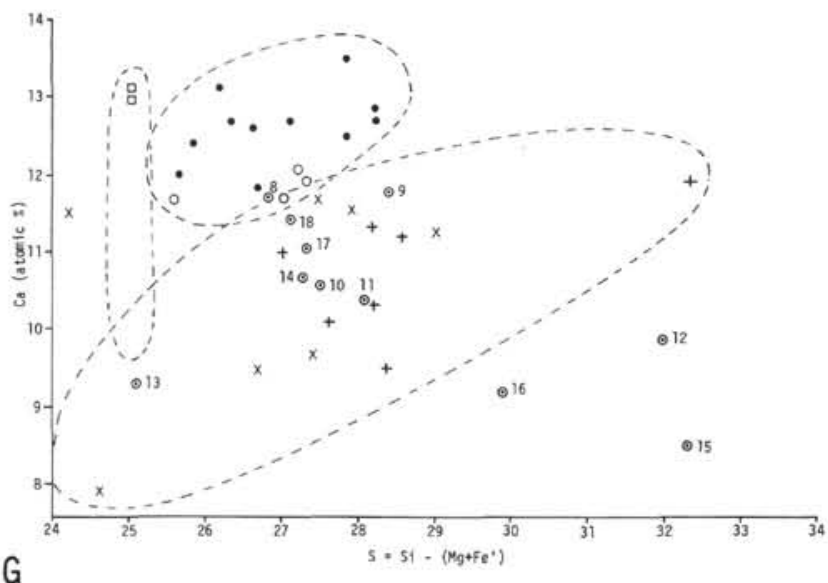

G

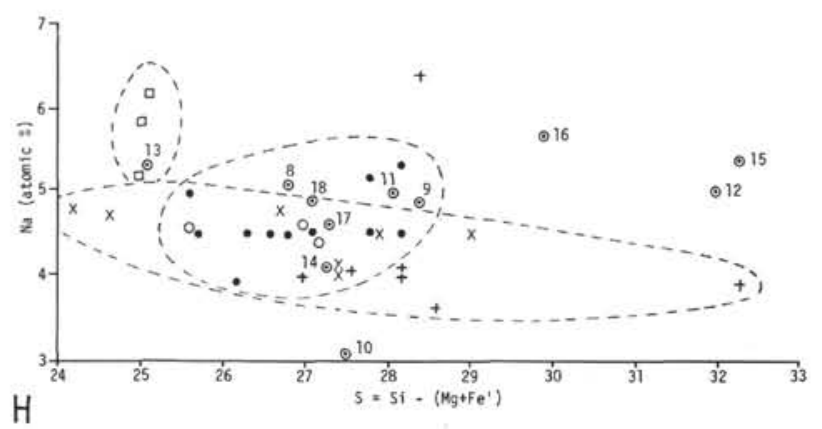

$\mathrm{H}$

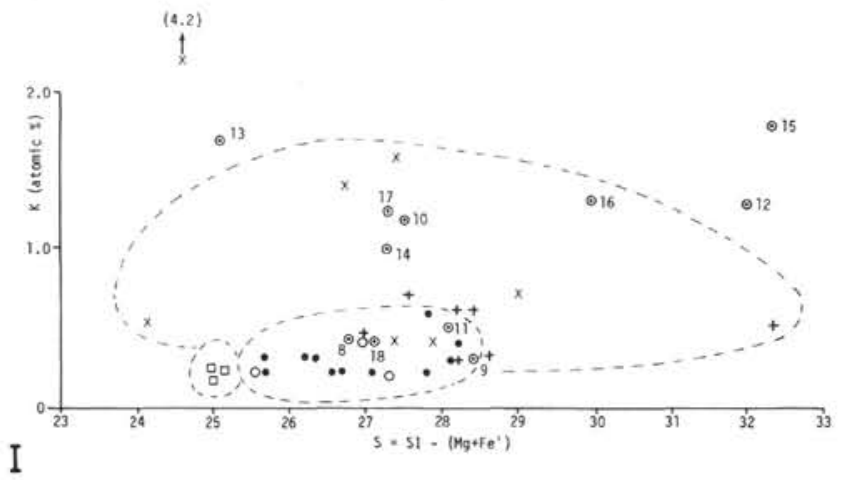

Figure 5. (Continued).

but lies outside the overall oceanic field and within the field of continental tholeiites, near its border with oceanic tholeiites. The peculiarity of the basalts from Site 236 lies in that such basalts tend to vary in composition from normal tholeiites to basalts belonging to the so-called "andesite suite" (Kutolin, 1972) which is extensive in island arcs and on continental margins. This assumption needs further confirmation because to date we have only one analysis which is very similar to that of typical basalts of the andesite suite.

One might believe that the range in composition of these basalts originates through great differences in the degree of partial melting of primary mantle material. A measure of this factor can be obtained by calculation of the proportionate distances between points corresponding to initial lherzolite, harzburgite (dunite), and basalt which lie on one straight line (Figure 4). Further, in such a case, the formation of basalts enriched in $\mathrm{Si}, \mathrm{Al}$, and $\mathrm{Ca}$, i.e., Sample 236-33-3a(4), Table 1, Column 8, could be accomplished by their outmelting from water-satruated mantle (Kurshiro, 1972; Allen et al., 1972).

The composition of the diabase sill encountered at Hole 233A near the Gulf of Aden differs from all the other flow and pillow basalts (Table 1). This rock is close to the average continental olivine basalt (Kutolin, 1972) in the concentration of the major petrochemical components. However, the Leg 24 diabases have low $\mathrm{Al}$ and $\mathrm{K}$ and a high concentration of $\mathrm{Ca}$.

Several comments follow on minor petrochemical components:

1) The titanium contents in the young basalts (Sites 231 and 238) are similar to those in the average oceanic ridge tholeiite.

2) The diabase sill (Hole 233A) is characterized by higher Ti content, as are the continental basalts.

3) Contrary to these recognizable relationships, the $\mathrm{Ti}$ content in the ancient basalts (Sites 235 and 236) is less than that in normal oceanic tholeiites and closer to that of island arc andesite basalts.

4) It is interesting as well that in all the Leg 24 samples the $\mathrm{Ti}$ distribution follows the trend in iron content in the same specimens: the more iron, the more titanium (Figures 5C, E, and 6B, D).

It is important that in all the Leg 24 basalts and diabases (except for several altered specimens) the potassium content remains low. One can conclude that in this respect our rocks "keep the faith" of oceanic tradition.

\section{PRELIMINARY CONCLUSIONS}

1) Petrochemical composition of the basaltic "basement" gradually changes from the crestal zone to the lower flanks of the mid-ocean ridge: all of the pillow basalts analyzed have a composition intermediate between oceanic and continental tholeiites. The initial step in this series is displayed by the young basalts covered by Miocene sediments (Site 231). The second step is represented by Paleocene(?) basalts (Site 236). A special state of magma generation is represented, perhaps, by the slightly differentiated group of Late Cretaceous(?) basalts (Site 235) which have properties similar to those of average gabbro.

2) The most favorable conditions for the development of crystallization differentiation were present at ancient times in the evolution of the Mid-Indian Ocean ridge system. Probably this stage corresponded to the initial appearance of this ridge.

3) The diabase sill (Site 233A) differs petrochemically from pillow basalts and has a composition very close to olivine basalts formed on continents.

4) All the Leg 24 basalts and diabase have the low potassium content characteristic for oceanic ridge basalts.

5) These first results of petrochemical study of the Leg 24 specimens are very encouraging: it may be possible in the near future to reconstruct the evolution of the ancient mantle in oceanic regions and the development of the oceanic crustal rocks from it. 

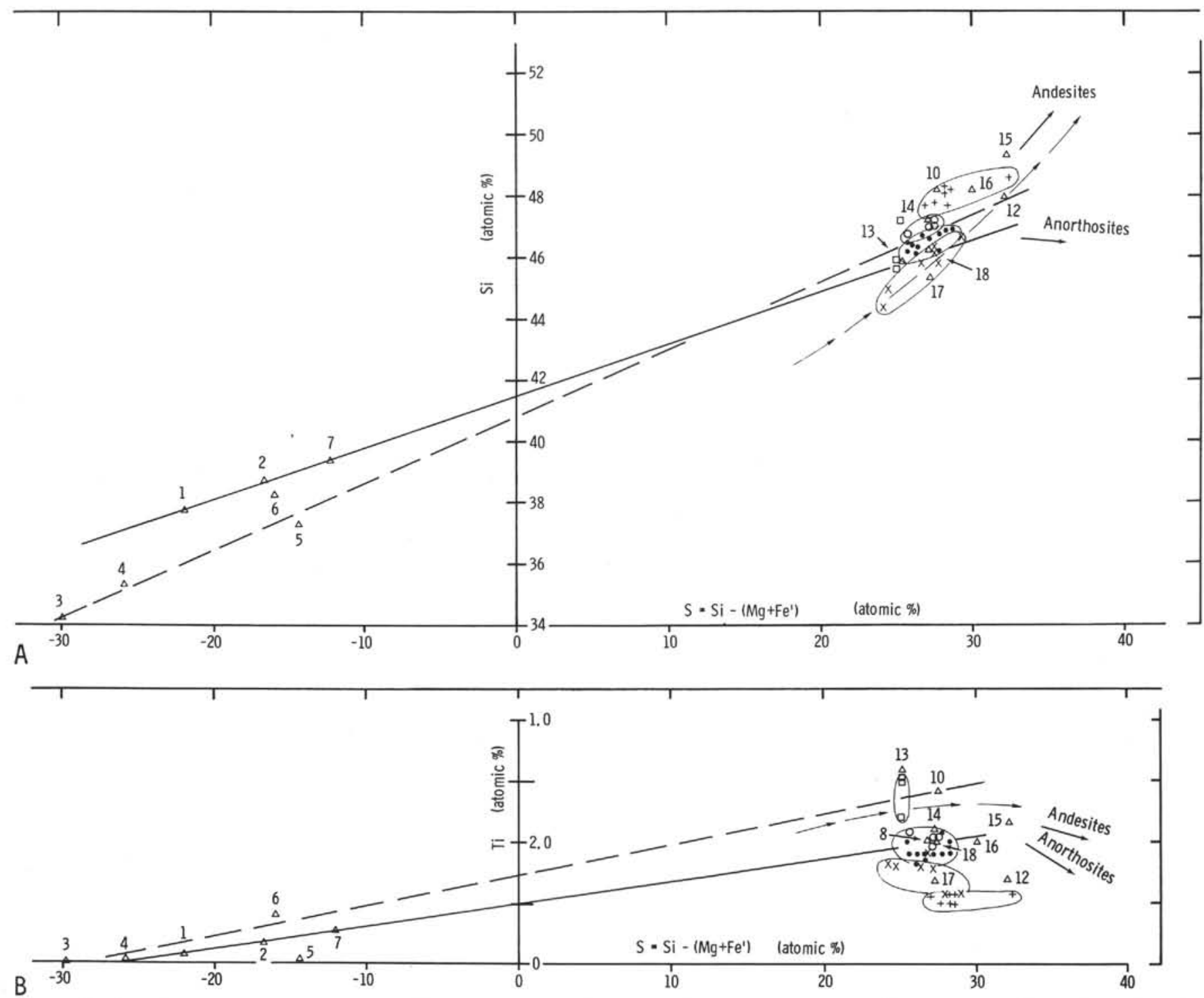

Figure 6. Correlation between parameter " $S$ " and several other petrochemical components for oceanic and continental mafic and ultramafic rocks in addition to mafics (basalts and diabase) from Leg 24: (A) Si; (B) $\mathrm{Ti}$; (C) $A l$; (D) $\mathrm{Fe}^{\prime}$; (E) $\mathrm{Mg}$; (F) $\mathrm{Ca} ;(\mathrm{G}) \mathrm{K} ; \mathrm{(H}) \mathrm{Na}$. Site symbols and rock types, same as before.

\section{REFERENCES}

Allen, J. C., Modreski, P. J., Hapgood, C., and Boettcher, A. L., 1972. The role of water in the mantle of the earth: the stability of amphiboles and micas (abstract). In Internatl. Geol. Congr., 24th Montreal, p. 35.

Daly, R. A., 1933. Igneous rocks and the depths of the earth; New York (McGraw-Hill).

Dmitriev, L. V., 1969. Origin of the ultrabasic rocks in the rift zones of the Indian Ocean Ridge (in Russian): Geokhiimia, no. 10, p. 1179-1187. (English translation in Geochem. Internatl,v. 6 no. 5, p. 923-931).

1972. Possible petrological consequence of the rise of mantle beneath mid-oceanic ridges (in Russian); Geokhiimia, no. 3, p. 266-271. (English translation in Geochem. Internatl, v. 9 , no. 2, p. 168-172.)

Dmitriev, L. V., Udintsev, G. B., and Sharas'kin, A. J., 1972a. The rift zones of oceans and the formation of oceanic crust (in Russian): In Tugarinov, A.I. (Ed.),
Features of modern geochemistry and analytical chemistry - a volume dedicated to Academician A.P. Vinogradov on his 75th birthday: Moscow (Nauka), p. 113-128.

Dmitriev, L. V., Ukhanov, A. V., and Sharas'kin, A. J., 1972b. Composition of the upper mantle (in Russian): Geokhiimia, no. 10, p. 1155-1167. (English translation in Geochem. Internatl., v. 9, no. 5, p. 781-792.)

Engel, A. E. J., Engel, C. G., and Havens, R. G., 1965. Chemical characteristics of oceanic basalts and the upper mantle: Geol. Soc. Am. Bull., v. 76, p. 719-734.

Green, D. H. and Ringwood, A. E., 1963. Mineral assemblages in a model mantle composition: J. Geophys. Res., v. 68, p. 937-945.

Hart, S. R., 1969. Rb, Cs contents and $\mathrm{K} / \mathrm{Rb}, \mathrm{K} / \mathrm{Cs}$ ratios of fresh and altered submarine basalts: Earth Planet. Sci. Lett., v. 6, p. 295-303.

Kuno, H., 1960. High-alumina basalt: J. Petrol., v. 1, p. 121-145. 


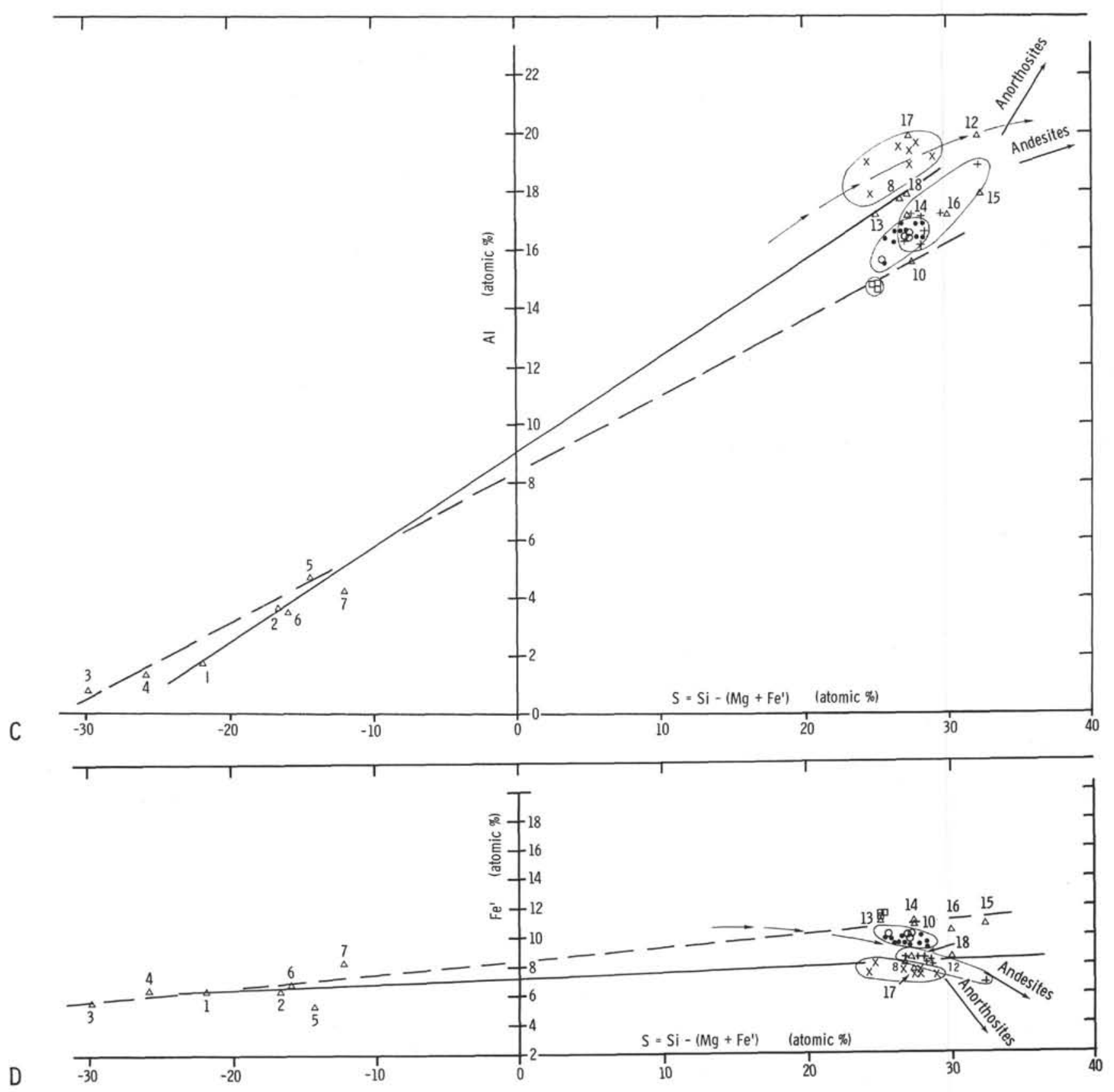

Figure 6. (Continued).

Kuno, H. and Aoki, K., 1970. Chemistry of ultramafic nodules and their bearing on the origin of basaltic magmas: Phys. Earth Planet. Inte., v. 3, p. 273-301.

Kushiro, I., 1972. Partial melting of peridotite in the presence of water and under dry conditions, and the origin of magmas. In Vinogradov, A. P. (Ed.), Report of First Intern. Geochem. Cong., v. 1; Vernadsky Inst. Acad. Sci. USSR, Moscow, p. 37-47.
Kutolin, V., 1972. Problems of basaltic petrochemistry and petrology: Novosibirsk (Nauka).

Nockolds, S. R., 1954. Average chemical composition of some igneous rocks: Geol Soc. Am. Bull. v. 65, p. 1007-1032.

Ringwood, A. E., 1966. The chemical composition and origin of the earth. In Hurley, P. M. (Ed.), Advances in Earth Science, Cambridge, (MIT Press), p. 287-356. 

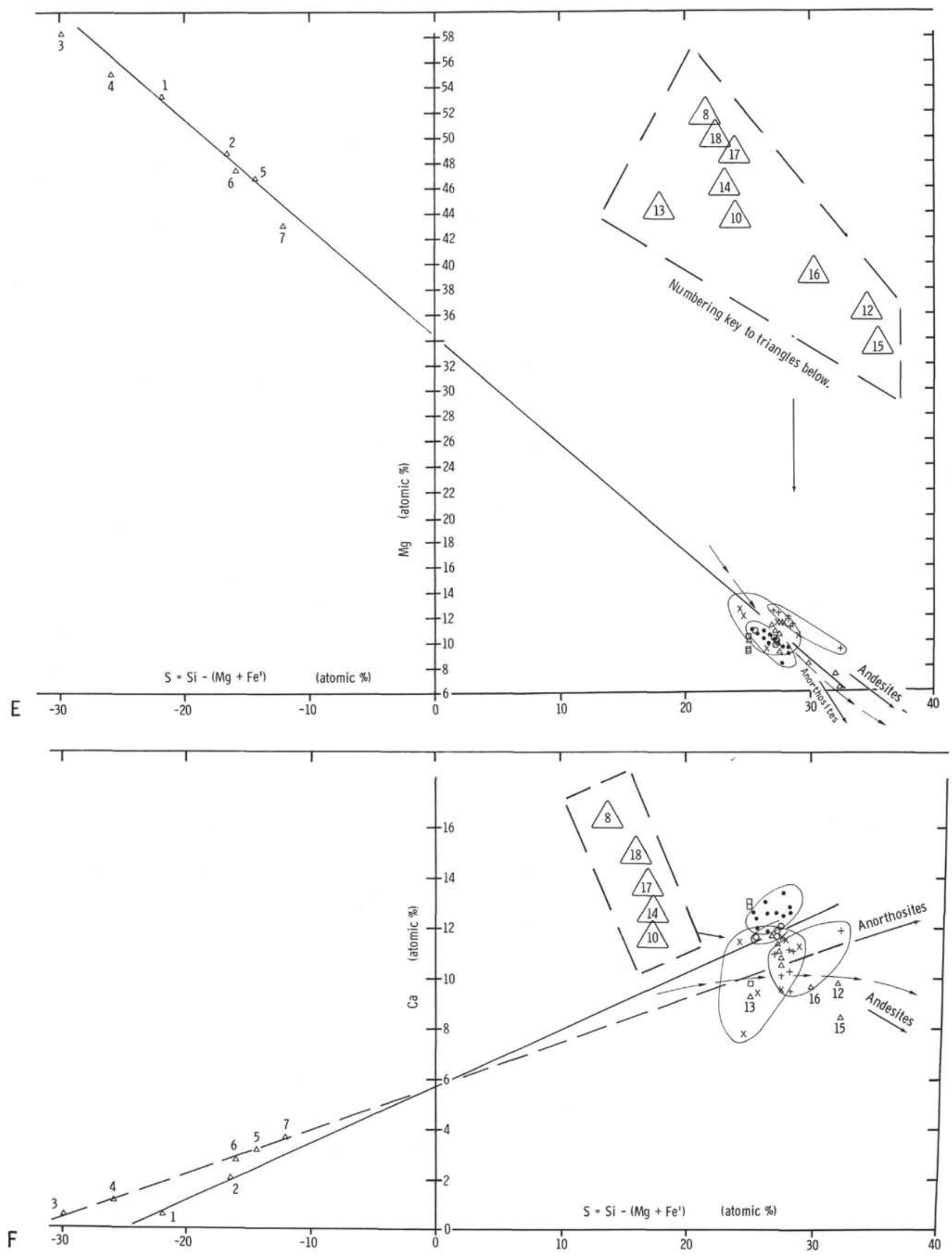

Figure 6. (Continued). 

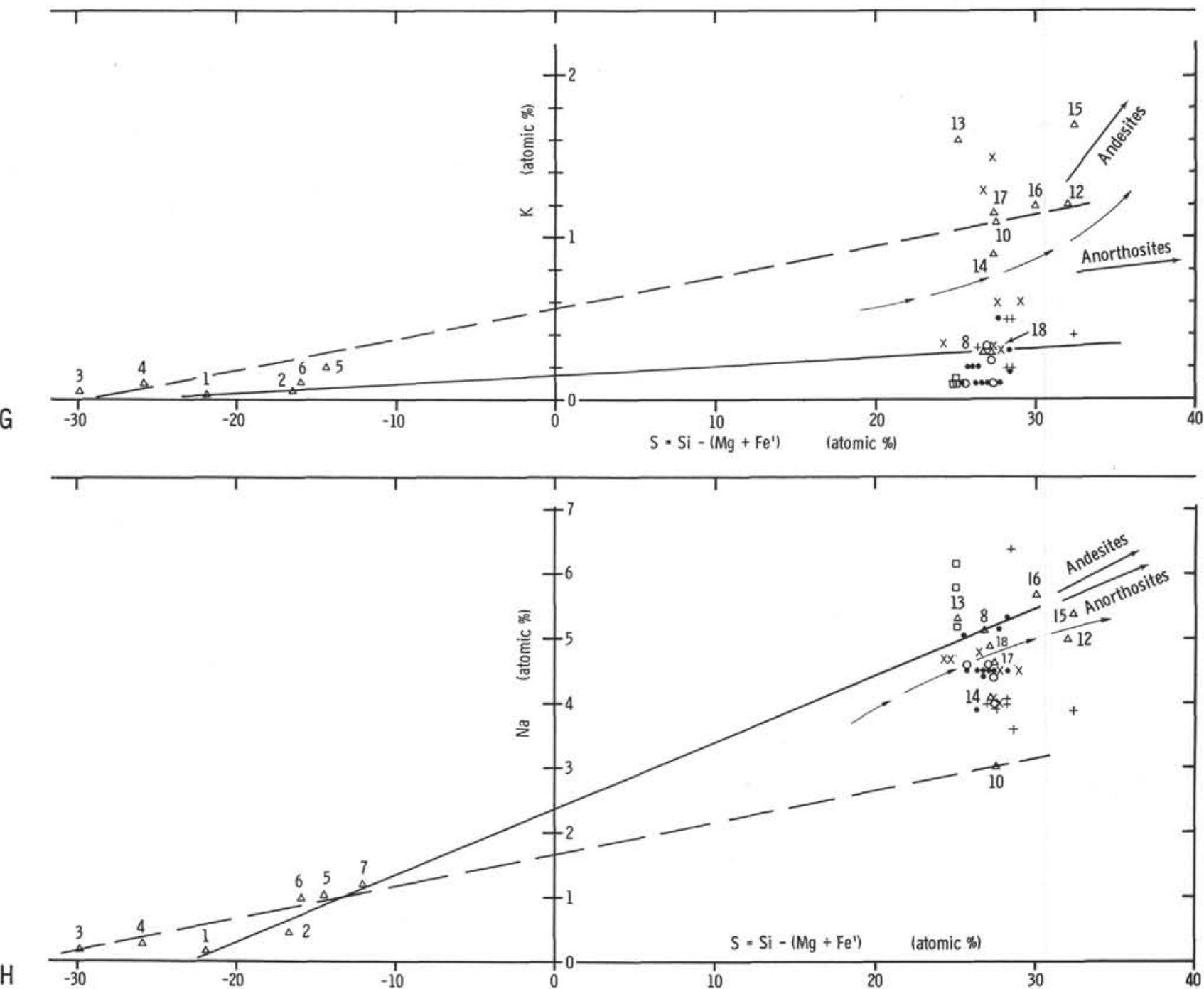

Figure 6. (Continued).

APPENDIX

Average Square Deviation $S=\left(\sqrt{\frac{\Sigma d^{2}}{n-1}}\right)$,

in Weight Percent, of Chemical Analyses for Mafic Rocks

\begin{tabular}{|c|c|c|}
\hline $\mathrm{SiO}_{2}$ & 0.12 & $\begin{array}{l}\text { Gravimetric precipitation, as a gelatin, under } \\
\text { acid medium }\end{array}$ \\
\hline $\mathrm{TiO}_{2}$ & 0.04 & Photocolorimetrically, with $\mathrm{H}_{2} \mathrm{O}_{2}$ \\
\hline $\mathrm{Al}_{2} \mathrm{O}_{3}$ & 0.17 & Titrimetrically, with xilenol orange \\
\hline $\mathrm{Fe}_{2} \mathrm{O}_{3}$ & 0.10 & Titrimetrically, with sulphosalicyclic acid \\
\hline $\mathrm{FeO}$ & 0.14 & Volumetrically, with $\mathrm{K}_{2} \mathrm{Cr}_{2} \mathrm{O}_{7}$ \\
\hline $\mathrm{MnO}$ & 0.09 & Photometrically, with $\mathrm{KIO}_{4}$ \\
\hline $\mathrm{MgO}$ & 0.09 & Titrimetrically, with chromogene black \\
\hline $\mathrm{CaO}$ & 0.10 & Titrimetrically, with fluorexone \\
\hline $\mathrm{Na}_{2} \mathrm{O}$ & 0.10 & Flame photometrically \\
\hline $\mathrm{K}_{2} \mathrm{O}$ & 0.01 & Flame photometrically \\
\hline $\mathrm{H}_{2} \mathrm{O}$ (total) & 0.10 & Gravimetrically \\
\hline
\end{tabular}

Note: Analyst: A. V. Lebedkova, Vernadsky Institute of Geochemistry, Academy of Sciences of the USSR. 